\title{
Development of transmucosal patch loaded with anesthetic and analgesic for dental procedures and in vivo evaluation [Corrigendum]
}

Nidhi M, Patro MN, Kusumvalli S, Kusumdevi V. Int J Nanomedicine. 2016;11:2901-2920.

On page 2905, section 'Transport of LB and DDEA across Caco-2 cell monolayer', some of the values were incorrectly presented. The corrected text should read:

Prior to transport, the culture medium was replaced by $600 \mu \mathrm{L}$ of transport medium (Dulbecco's Modified Eagle's Medium [DMEM]-F12-buffered with 4-(2-hydroxyethyl)-1piperazineethanesulfonic acid [HEPES]), 10\% fetal bovine serum, and antibiotics penstrip $(1 \% \mathrm{v} / \mathrm{v})$, gentamicin $(250 \mu \mathrm{g} / \mathrm{mL})$, and chloramphenicol $(23 \mathrm{ng} / \mathrm{mL})$, and cells were allowed to equilibrate for 30 minutes. After the transport medium was discarded, $600 \mu \mathrm{L}$ of pure drugs LB, DDEA, DDEA-SLN, and TP prepared in dimethyl sulfoxide $(10 \% \mathrm{w} / \mathrm{v})$ suspended in DMEM-F12-HEPES was applied to the apical side, and $600 \mu \mathrm{L}$ of DMEM-F12-HEPES was added to the basolateral (BL) side. At predetermined time intervals, transepithelial electrical resistance was measured, and $50 \mu \mathrm{L}$ of the aliquot was withdrawn from the BL side for quantification of the transported drug.
International Journal of Nanomedicine

\section{Publish your work in this journal}

The International Journal of Nanomedicine is an international, peerreviewed journal focusing on the application of nanotechnology in diagnostics, therapeutics, and drug delivery systems throughout the biomedical field. This journal is indexed on PubMed Central, MedLine, CAS, SciSearch ${ }^{\circledR}$, Current Contents ${ }^{\circledR} /$ Clinical Medicine,

\section{Dovepress}

Journal Citation Reports/Science Edition, EMBase, Scopus and the Elsevier Bibliographic databases. The manuscript management system is completely online and includes a very quick and fair peer-review system, which is all easy to use. Visit http://www.dovepress.com/ testimonials.php to read real quotes from published authors. 